\title{
Niewykorzystany potencjał kultu religijnego miejscowości wiejskiej. Przykład Świnic Warckich w województwie łódzkim
}

\section{Untapped religious potential of rural locality. Example of Świnice Warckie in the Łódzkie Voivodeship}

\section{Andrzej SULIBORSKI • Anita KULAWIAK}

\author{
Uniwersytet Łódzki \\ Katedra Geografii Regionalnej i Społecznej \\ ul. Kopcińskiego 31, 90-142 Łódź \\ andrzej.suliborski@geo.uni.lodz.pl•anita.kulawiak@geo.uni.lodz.pl
}

\begin{abstract}
Zarys treści: Współcześnie podstawową rolę w rozwoju społeczno-gospodarczym miejscowości odgrywają zasoby lokalne rozumiane jako potencjał tkwiący w układach społeczno-terytorialnych poziomu lokalnego i regionalnego. Jednym z takich zasobów jest treść materialna i duchowa związana z określonym kultem religijnym. Religia od zawsze stanowiła istotny czynnik osadniczotwórczy. Pojawienie się masowego ruchu pielgrzymkowego prowadziło do powstania punktu osadniczego przekształcanego często w osiedle, a później w miasto i odwrotnie, zanik pielgrzymek stawał się przyczyną upadku gospodarczego i degradacji społecznej danej miejscowości. Głównym celem artykułu jest identyfikacja Sanktuarium Urodzin i Chrztu Św. Faustyny - związanego z kultem Miłosierdzia Bożego oraz jego znaczenia w rozwoju gospodarczym i życiu mieszkańców małej miejscowości wiejskiej Świnice Warckie. W artykule określono religijną i społeczną istotę kultu oraz Sanktuarium, wagę Świnic Warckich pośród innych miejsc kultowych tego typu oraz rozpoznano formy (sposoby) jego uprawiania oraz wpływ na życie gospodarcze i społeczne mieszkańców.
\end{abstract}

Słowa kluczowe: wieś, funkcja religijna miejscowości wiejskiej, kult Bożego Miłosierdzia.

\section{Wprowadzenie}

Religia zawsze odgrywała ważną rolę w życiu poszczególnych wspólnot, narodów czy krajów. Już w czasach pogańskich istniała rozwinięta sieć miejsc świętych, do których zdążali członkowie różnych plemion w celu oddania czci bóstwu, przedstawienia mu swoich kłopotów lub złożenia podziękowań za okazaną pomoc (Jackowski 2003). Świątynie były jednym z najważniejszych obiektów i miejsc zarówno w przestrzeni miast antycznych, jak i nowożytnych, zarówno tych przedlokacyjnych, jak i lokacyjnych (gotyckich). W opinii historyków i religioznawców miejsca i obiekty święte oraz związane z nimi pielgrzymki ludzi od zawsze odgrywały zasadniczą rolę w procesie rozwoju miejscowości i powstaniu miast (patrz: Klima 2011; Sołjan 2012). W efekcie wzmożonego ruchu pielgrzymkowego dochodziło często do zmiany charakteru miejsca - zakładania osady lub przekształcania jej do- 
tychczasowej struktury przestrzennej, gospodarczej i fizjonomicznej, a nierzadko również do jej wzrostu i awansu administracyjnego. Natomiast zanik ruchu pielgrzymkowego był przyczyną regresu gospodarczego ośrodka i powodował obniżenie warunków życia ludności, a nawet jej emigrację.

Współcześnie funkcji religijnej przypisuje się również duże znaczenie w rozwoju społeczno-gospodarczym miejscowości, wynikające z tego, że jest ona silną stymulantą powstawania różnych nowych podmiotów gospodarczych, w tym niekoniecznie związanych z funkcją religijną. Istniejące dzisiaj centra religijne - poza walorami religijnymi - oferują przybywającym również dostęp do wielu usług i atrakcji pozareligijnych, które wymagają rozwoju infrastruktury gospodarczej wspomagającej miejsce kultu i samą miejscowość. W ośrodkach takich powstają obiekty bazy noclegowej, gastronomicznej, handlowej (sprzedaż dewocjonaliów, artykułów żywnościowych i przemysłowych), rzemiosła (wyrób dewocjonaliów), transportu, biur turystycznych, a często również nauki i oświaty (w miejscowościach religijnych znajdują się uczelnie, w których kształcą się wyznawcy danej religii). W konsekwencji zachodzących zmian następować może spadek bezrobocia, wzrost poziomu zamożności społeczeństwa i poprawa warunków i jakości życia mieszkańców. Miejsca kultu religijnego, poza niematerialnymi wartościami sakralnymi, mają często różne walory poznawcze: artystyczne, historyczne lub kulturowe, które sprzyjają rozwojowi także innych form aktywności ludzkiej. Nierzadko są one położone na obszarze interesującym pod względem krajobrazowym, co sprawia, że miejsca te są atrakcyjne zarówno dla pielgrzymów, jak i turystów.

Literatura przedmiotu dowodzi, że szczególnie silne znaczenie dla rozwoju miejscowości (miast) od zawsze odgrywały sanktuaria, za przykład można podać: Rzym, Waranasi, Jerozolimę czy Mekkę (Liszewski i Maik 2000; Jackowski i Sołjan 2008, 2010; Jackowski, Bilska-Wodecka, Sołjan, Quarini-Popławski 2009, Jackowski A., Sołjan I., Bilska-Wodecka E. 1999, Kosmaczewska 2011). Pojęciem sanktuarium określamy miejsce święte o szczególnym znaczeniu kultowym, zwykle budowlę sakralną lub jej najważniejszą część. Według I. Sołjan (2012) sanktuarium jest miejscem wyjątkowym, w odróżnieniu od innych miejsc sakralnych, ze względu na obiekt kultu religijnego niespotykany w innych ośrodkach (np. relikwie, wizerunki słynące łaskami, objawienia Boga), który przyciąga pielgrzymów. W religii katolickiej za sanktuarium uważany jest „kościół lub inne miejsce święte, do którego za aprobatą ordynariusza - pielgrzymują liczni wierni, z powodu szczególnej pobożności" (Kodeks Prawa Kanonicznego 1984, za: Flaga 2011, s. 113). Warto dodać, że pomimo iż otrzymanie miana „sanktuarium” zależy obecnie od decyzji miejscowego biskupa, to większość miejsc świętych zdobywa je przez długą tradycję napływu wiernych, co wymusza często milczącą akceptację władzy kościelnej (Flaga 2011).

Wpływ sanktuarium na otaczającą go przestrzeń może być różny, gdyż zależy od kilku czynników, z których najistotniejsze to: uwarunkowania genetyczno-historyczne sanktuarium, okres powstania miasta i sanktuarium, ranga i zasięg jego oddziaływania oraz wielkość i funkcje miejscowości (Sołjan 2012).

W sensie regionalistycznym najważniejsza jest jednak dokonująca się poprzez akt tworzenia sanktuarium waloryzacja przestrzeni, która w ten sposób staje się przestrzenią uświęconą, zdecydowanie odmienną od otaczającej ją przestrzeni świeckiej. Natomiast z perspektywy geografii religii sanktuarium może być podmiotem organizującym i zagospodarowującym nacechowaną religijnie przestrzeń lub/oraz kształtować przestrzeń na zewnątrz - poza sanktuarium (Park 1994) i tym samym oddziaływać na strukturę prze- 
strzenno-gospodarczą miejscowości. Uwzględniając sposób organizacji przestrzeni oraz oferowane przez dany ośrodek formy możliwej aktywności pielgrzymów i turystów, wyróżnia się następujące typy założeń sanktuaryjnych: inicjalne, proste, rozwinięte i złożone (Sołjan 2011).

W artykule podjęto problem wykorzystania specyficznego zasobu lokalnego (materialnego i duchowego), którym jest Sanktuarium Urodzin i Chrztu Św. Faustyny i związany z nim kult Miłosierdzia Bożego w małej miejscowość wiejskiej Świnice Warckie, jako czynnika stymulującego jej rozwój. Sanktuarium i kult, rozpatrywane jako swoisty potencjał tkwiący szczególnie w małych i biednych układach społeczno-terytorialnych, stanowi ważne, a zarazem słabo rozpoznane zagadnienie badawcze.

Celem badań była z jednej strony szeroka identyfikacja kultu oraz związanego z nim sanktuarium, z drugiej określenie ich znaczenia dla życia społecznego i gospodarczego miejscowości, w której się znajdują. Realizacja celu głównego wymagała: opisu lokalnych uwarunkowań rozwoju gospodarczego Świnic Warckich, wyjaśnienia istoty kultu Miłosierdzia Bożego oraz roli św. Faustyny w jego upowszechnieniu, ustalenia pozycji Świnic Warckich pośród innych miejsc kultu Bożego Miłosierdzia, identyfikacji znaczenia religijnego Świnic Warckich - form (sposobów) wyznawania kultu i jego wpływu na życie mieszkańców.

Świnice Warckie położone są w województwie łódzkim i należą do diecezji włocławskiej. Są jednym z najważniejszych w Polsce miejsc kultu Bożego Miłosierdzia, w którym znajduje się Sanktuarium Urodzin i Chrztu św. Siostry Faustyny. Co roku przybywa tu blisko 13 tys. pielgrzymów. Ranga religijna tego miejsca, co najmniej o charakterze ogólnokrajowym, powinna stanowić istotną przesłankę dla planowania rozwoju miejscowości.

W badaniach wykorzystano dwa źródła informacji: inwentaryzację terenową przeprowadzoną w marcu 2016 r. w miejscowości Świnice Warckie oraz kwerendę w Urzędzie Gminy Świnice Warckie, gminnej bibliotece publicznej oraz w gminnym ośrodku kultury. W trakcie badań zebrano m.in. informacje na temat historii gminy i miejscowości, a także jej życia społeczno-gospodarczego oraz zarejestrowano zmiany, głównie o charakterze przestrzennym i funkcjonalnym, jakie zaszły na jej terenie pod wpływem kultu. Drugim źródłem wiedzy były wywiady kwestionariuszowe i swobodne, przeprowadzone zarówno z mieszkańcami wsi, pielgrzymami oraz osobami ważnymi dla społeczności lokalnej, w tym z proboszczem miejscowej parafii, dyrektorem gminnego ośrodka kultury oraz dyrektorem miejskiej biblioteki publicznej. W badaniu uczestniczyło 165 osób. Wyniki wykorzystano do identyfikacji sposobów realizacji kultu św. Faustyny w Świnicach Warckich oraz jego wpływu na życie mieszkańców i gospodarkę miejscowości.

\section{Uwarunkowania lokalne rozwoju gospodarczego Świnić Warckich}

Miejscowość Świnice Warckie w latach 1388-1466 była niewielkim miastem, liczącym zaledwie 1 tys. mieszkańców, które powstało na gruntach dawnej wsi szlacheckiej o słabo wykształconym układzie przestrzennym. Obecnie mają one status wsi sołeckiej i jednocześnie są siedzibą władz gminnych. Leżą w północno-zachodniej części województwa łódzkiego, na peryferiach powiatu łęczyckiego. Sieć dróg w gminie jest słabo rozwinięta, co wpływa na ograniczoną dostępność drogową miejscowości, przez którą przechodzi jedna droga powiatowa (nr 2523). Prowadzi ona w kierunku wschodnim do Łęczycy (20 km) i umożliwia dojazd do autostrady A2, łączącej Poznań z Warszawą, a także do drogi woje- 
wódzkiej łączącej m.in. Dąbie n. Nerem z Uniejowem (nr 473). Ze Świnic Warckich wybiegają jeszcze dwie drogi gminne: pierwsza na wschód w kierunku Wartkowic, przez Saków, Dzierżawy i Targową oraz druga na zachód przez Kraski i Stemplew do drogi wojewódzkiej nr 473 łączącej Uniejów z Dąbiem i autostradą A2, a także drogi gruntowe łączące poszczególne wsie w gminie. Autostrada A2 nie ma bezpośredniego powiązania z całym układem drogowym gminy - najbliższy wyjazd znajduje się w miejscowościach Domanin (9km) lub Pełczyska $(16 \mathrm{~km})$. Świnice Warckie obsługiwane są zaledwie przez jednego przewoźnika PKS-Łęczyca, który zapewnia bezpośrednie połączenia na trzech liniach: z Łęczycą (13 kursów w ciągu doby), Łodzią (1 kurs), Stemplewem (4 kursy) oraz Zbylczycami (1 kurs).

W sąsiedztwie Świnic Warckich przebiega główna magistrala kolejowa Polski (nr 131) łącząca Śląsk z Gdynią. Najbliżej położona (w odległości 1 km) stacja kolejowa w Kraskach już nie funkcjonuje, w związku z czym Świnice nie mają dostępu do krajowej sieci kolejowej (do niedawna było jeszcze jedno połączenie na dobę z Łodzią przez Zduńską Wolę).

W stosunkowo bliskiej odległości od Świnic Warckich (do 35 km) położone są interesujące turystycznie miejscowości i obiekty, jak: Uniejów - uzdrowisko z zamkiem biskupów włocławskich, Łęczyca - stolica powiatu, miasto o średniowiecznym założeniu z zamkiem Kazimierza Wielkiego, Kłodawa z czynną kopalnią soli udostępnianą do zwiedzania, zalew na Warcie o nazwie Jeziorsko, Poddębice z renesansowym kościołem i zamkiem, ruiny zamku Biesiekiery, dwory i parki podworskie (np. dwór w miejscowości Gusin, w którym w latach 1872-1877 mieszkała i tworzyła Maria Konopnicka), Zbylczyce, Parski, Kozaki oraz inne. Przez teren gminy przechodzi 8 oznakowanych szlaków turystycznych.

Istniejący system komunikacyjny powoduje, że Świnice Warckie są generalnie słabo skomunikowane zarówno z sąsiednimi ośrodkami, jak i resztą kraju. Ustronność położenia wsi jest zatem poważną barierę ograniczającą możliwość napływu pielgrzymów oraz turystów (ryc. 1)

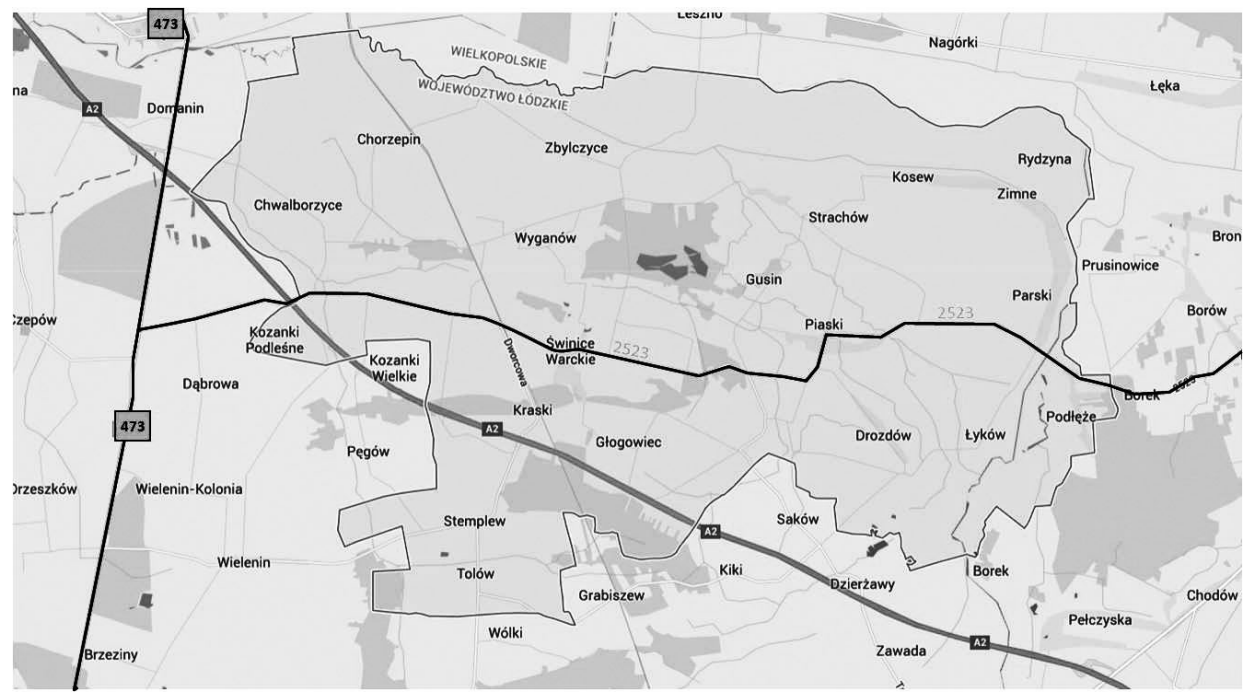

Ryc. 1. Dostępność komunikacyjna Świnic Warckich Transport accessibility to Świnice Warckie Źródło/Source: opracowanie własne na podstawie/own elaboration based on: Strategia Rozwoju Gminy Świnice Warckie na lata 2015-2024. 
Gmina Świnice Warckie, podobnie jak pobliski Uniejów i Poddębice, ma zasoby wód geotermalnych, których temperatura oraz skład mineralny stwarzają potencjalne możliwości ich wykorzystania rekreacyjno-leczniczego. Wieś położona jest na obszarze o interesujących walorach krajobrazowych doliny rzeki Warty oraz jej prawego dopływu Neru (Obszar Chronionego Krajobrazu Doliny Warty i Neru). Krajobraz urozmaicają również niewielkie wzniesienia wydmowe oraz malownicze zakola rzeki Ner i jej starorzecza wypełnione wodą. W bliskiej przyszłości na tym obszarze ma powstać rezerwat faunistyczny ptaków „Dąbskie Błota”. Całą gminę cechuje dobry poziom rozwoju gospodarczego, o czym świadczy najwyższy w powiecie łęczyckim wskaźnik poziomu przedsiębiorczości - 174 podmiotów gospodarczych na 10 tys. osób (BDL 2016).

Wieś Świnice Warckie zajmuje powierzchnię 263 ha (niecałe 3\% ogólnej powierzchni gminy) i należy do najmniejszych obszarowo jednostek osadniczych gminy. Zamieszkuje ją około 650 osób, co stanowi 16\% całej ludności gminy (BDL 2016). Miejscowość wyposażona jest w kanalizację i oczyszczalnię ścieków, własną hydrofornię i prowadzi selektywną zbiórkę odpadów. Spośród innych ośrodków gminnych powiatu łęczyckiego wyróżnia się większym odsetkiem podmiotów gospodarczych w sekcjach (I, R, J, G), które w części mogą obsługiwać ludność przybyłą tutaj jako pielgrzymi czy turyści. Wymienione sekcje łącznie skupiają blisko 50\% wszystkich podmiotów zlokalizowanych w miejscowości, podczas gdy w innych ośrodkach gminnych ich udział nie przekracza 45\% (BDL 2016). Świnice Warckie są typowym ośrodkiem lokalnym - centrum administracyjno-usługowym (skupia ponad 50\% wszystkich podmiotów gospodarczych gmin) oraz kulturalno-oświatowym dla okolicy. Tutaj zlokalizowane są najważniejsze i największe w gminie instytucje, jak: urząd gminy, Spółdzielcze Koło Rolnicze, Rolnicza Spółdzielnia Produkcyjna, ośrodek zdrowia, poczta, bank, gimnazjum i szkoła podstawowa, gminny ośrodek kultury, gminna biblioteka publiczna oraz punkt informacji turystycznej. Odbywają się tu również wszystkie ważne i popularne wśród mieszkańców gminy i okolic imprezy i uroczystości, m.in. Święto Ziemniaka, Przegląd Orkiestr Dętych Powiatu Łęczyckiego czy Integracyjny Festiwal Pieśni ku czci św. Faustyny „Miłosierne Nutki”. Wieś pod względem zagospodarowania, wyposażenia instytucjonalnego oraz aktywności kulturalno-oświatowej spełnia wszystkie wymogi do uzyskania praw miejskich.

Najważniejszym jednak zasobem i równocześnie walorem kulturowym Świnic Warckich jest Sanktuarium Urodzin i Chrztu św. Faustyny związane z kultem Bożego Miłosierdzia. Ma ono charakter złożony, którego rdzeniem jest kościół p.w. św. Kazimierza, w którym przechowywane są relikwie świętej. Ponadto w skład sanktuarium wchodzą inne obiekty:

- sakralne - kaplica Matki Boskiej i droga krzyżowa,

- o charakterze religijnym, ale niepełniące funkcji kultowych - Klasztor Zgromadzenia Sióstr Matki Bożej Miłosierdzia,

- muzeum - dom rodzinny św. siostry Faustyny,

- oraz sklepik z dewocjonaliami i kafejka służące bezpośrednio pielgrzymom.

Sanktuarium oraz funkcja administracyjna Świnic Warckich (siedziba gminy) są głównymi czynnikami, których synergiczne działanie, przy wykorzystaniu innych zasobów przyrodniczych i kulturowych znajdujących się w otoczeniu miejscowości, może stanowić dobry punkt wyjścia do lepszego rozwoju miejscowości. 


\section{Rola św. Faustyny w rozpowszechnieniu kultu Miłosierdzia Bożego}

W teologii chrześcijańskiej Miłosierdzie jest uznawane za największy z przymiotów Boga, jest Jego łaską dla świata. Polega ono na bezgranicznej dobroci dla ludzi potrzebujących, w tym przede wszystkim dla grzeszników, którym Jezus chce wszystko wybaczyć. Jego podstawą jest chrześcijańska ufność względem Boga i czynienie miłości wobec bliźnich, a także głoszenie i wypraszanie miłosierdzia Bożego dla świata, między innymi przez praktykę nowych form kultu, jak: obraz Jezusa Miłosiernego, święto Miłosierdzia, koronka i godzina Miłosierdzia.

Współcześnie kult Bożego Miłosierdzia należy do grona najważniejszych kultów w Kościele katolickim i mimo że należy do najmłodszych, cieszy się ogromną popularnością zarówno w Polsce, jak i za granicą. O jego znaczeniu w polskim Kościele świadczy m.in. fakt, że już w 1988 r. obraz Jezusa Miłosiernego znajdował się w 1620 kościołach i kaplicach Polski, w tym w 40 obdarzany był szczególną czcią. W 18 diecezjach odprawiane były nabożeństwa do Miłosierdzia Bożego, a w 826 kościołach w II niedzielę po Wielkanocy obchodzono święto Miłosierdzia Bożego. Nowennę i koronkę do Miłosierdzia Bożego odprawiano natomiast w 1589 ośrodkach kultu (Socha 2000).

Jezus Chrystus przekazał orędzie o Bożym Miłosierdziu kościołowi za pośrednictwem św. Faustyny, co potwierdzili oficjalnie papieże, a szczególnie Jan Paweł II w swojej encyklice Dives in misericordia (2002). Początki kultu w formie zaproponowanej przez św. Faustynę sięgają okresu międzywojennego i wiążą się z uzyskaniem w 1937 r. przez ks. Macieja Sopoćkę (spowiednika i przewodnika duchowego świętej) zgody na zawieszenie w ołtarzu głównym kościoła p.w. św. Michała w Wilnie obrazu „Jezu ufam Tobie” powstałego na podstawie treści jej objawienia. W 1937 r. drukiem ukazała się książeczka „Dzienniczek” zawierająca modlitwy podyktowane siostrze Faustynie przez samego Chrystusa, tj. koronkę i nowennę oraz szereg wezwań na cześć Miłosierdzia Bożego. W tym również czasie, początkowo w Wilnie, a następnie także w innych kościołach w Polsce, zainicjowano nabożeństwo do Miłosierdzia Bożego, które za pośrednictwem emigrantów polskich dotarło także do innych krajów. Najwcześniej rozpowszechnił się kult obrazu Jezusa Miłosiernego, ale bardzo szybko przyjęły się także pozostałe formy kultu, jak: nowenna i koronka do Miłosierdzia Bożego wraz z litanią. W czasie II wojny światowej teksty nowenny, koronki oraz litanii pojawiły się w językach: niemieckim, litewskim, francuskim, włoskim i angielskim. Po 1946 r. w sprawę szerzenia Bożego Miłosierdzia zaangażowali się polscy biskupi. Między innymi skierowali oni prośbę do Stolicy Apostolskiej o ustanowienie święta Miłosierdzia Bożego, w myśl siostry Faustyny. Niestety, wobec braku autorytatywnego stwierdzenia wiarygodności prywatnych objawień, nie wyrażono na nie zgody. Nie osłabiło to jednak spontanicznego rozwoju kultu w Polsce, a także za granicą, o czym świadczy fakt, że już w latach 50 XX w. był on znany w całej Europie, obu Amerykach, Australii, a także w wielu krajach Azji i Afryki. Obrazek Jezusa Miłosiernego z podpisem „Jezu, ufam Tobie”, jako najprostszy symbol kultu, doczekał się aż 60 wersji językowych. W latach 1956-1978, mimo stale wzrastającej popularności, notyfikacją Najwyższej Świętej Kongregacji Świętego Oficjum szerzenie kultu w formie zaproponowanej przez siostrę Faustynę oficjalnie zostało zakazane. Narzucone odgórnie ograniczenia - podobnie jak wcześniej - nie osłabiły jego rozwoju i znaczenia. Za sprawą papieża Jana Pawła II oraz polskich biskupów temat Miłosierdzia Bożego został zgłębiony naukowo, w efekcie czego w 1993 r. przeprowadzono proces beatyfikacji siostry Faustyny, a w siedem lat później, w 2000 r., wyniesiono ją na ołtarze 
i ustanowiono święto Bożego Miłosierdzia (Adonai.pl). W 2002 r. Jan Paweł II ustanowił Światowe Sanktuarium Miłosierdzia Bożego w Krakowie-Łagiewnikach, które jest ukoronowaniem i oficjalnym przypieczętowaniem kultu Bożego Miłosierdzia w Kościele katolickim oraz roli, jaką odegrała św. Faustyna w jego upowszechnieniu. O randze kultu w tradycji katolickiej w Polsce świadczy między innymi ustanowienie w kilku diecezjach sanktuariów Miłosierdzia Bożego oraz przyjmowanie przez nowe kościoły tytułu Miłosierdzia Bożego, natomiast o znaczeniu międzynarodowym świadczy fakt, że Sanktuarium Miłosierdzia Bożego w Łagiewnikach odwiedzają pielgrzymi pochodzący z różnych stron świata².

\section{Sanktuarium w Świnicach Warckich na tle innych miejsc świętych w Polsce związanych z kultem Miłosierdzia Bożego}

W Polsce istnieją aktualnie 24 sanktuaria szerzące kult Bożego Miłosierdzia, spośród których największe znaczenie mają cztery, gdyż bezpośrednio związane są z obecnością w tych miejscach św. Faustyny (ryc. 2). Są to: wspomniane już Światowe Centrum Kultu Bożego Miłosierdzia w Krakowie-Łagiewnikach, Sanktuarium Miłosierdzia Bożego w Białymstoku, Sanktuarium Miłosierdzia Bożego w Płocku oraz Sanktuarium Urodzin i Chrztu św. Siostry Faustyny w Świnicach Warckich.

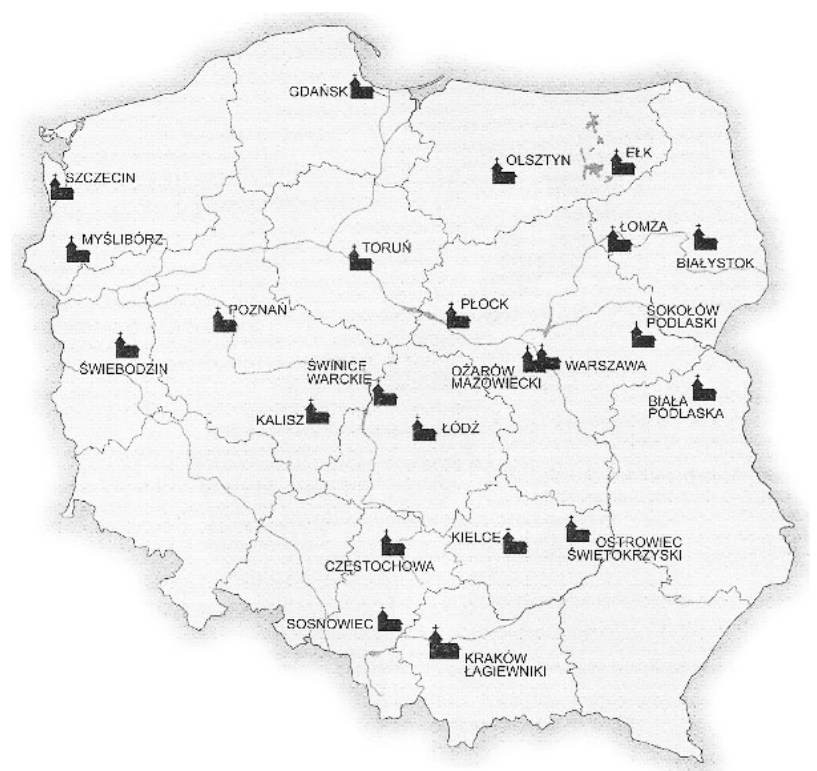

Ryc. 2. Rozmieszczenie sanktuariów Miłosierdzia Bożego w Polsce Distribution of Divine Mercy sanctuaries in Poland Źródło/Source: E. Czaczkowska (2012).

1 Sanktuaria Bożego Miłosierdzia ustanowiono m.in. w archidiecezjach: częstochowskiej (w Dolinie Miłosierdzia), krakowskiej (w Łagiewnikach), warszawskiej (w Ożarowie Mazowieckim), szczecińsko-kamieńskiej (w Szczecinie i Myśliborzu), kaliskiej (w Kaliszu), a także ostatnio w diecezji włocławskiej - w Świnicach Warckich (Socha 2000).

2 Pielgrzymi pochodzą m.in. z Austrii, Anglii, Irlandii, Niemiec, Słowacji, Czech, USA, Argentyny, Meksyku, Urugwaju, Tajlandii, Japonii i wielu innych krajów. 
Sanktuarium Bożego Miłosierdzia w Krakowie-Łagiewnikach jest obecnie najbardziej dynamicznym ośrodkiem tego kultu. Rokrocznie odwiedza go blisko $2 \mathrm{mln}$ pielgrzymów z całego świata. W kościele znajduje się słynący łaskami obraz Jezusa Miłosiernego pędzla A. Hyły, ufundowany jako wotum za ocalenie rodziny z wypadków wojennych przez spowiednika świętej Faustyny o. J. Andrasza oraz relikwie i grób świętej. Na popularność tego sanktuarium wpływa również fakt, że siostra Faustyna pełniła tutaj swoją posługę duszpasterską jako młoda dziewczyna i w tym miejscu narodziło się orędzie Miłosierdzia Bożego przekazane ludziom przez Jezusa. Pierwsze nabożeństwa w Krakowie-Łagiewnikach ku czci Bożego Miłosierdzia rozpoczęły się w 1943 r. Dzisiaj w sanktuarium odbywa się wiele mszy i uroczystości związanych z tym kultem. Codziennie odprawiana jest godzina Miłosierdzia i Koronka, co wtorek msza św. ku czci św. Faustyny, w każdy czwartek msza do Miłosierdzia Bożego w intencji składanych próśb i podziękowań. Sanktuarium jest bardzo aktywne pod względem działalności naukowej i wydawniczej. Odbywają się w nim m.in. sympozja naukowe i konferencje poświęcone życiu i działalności św. Faustyny.

Sanktuarium Miłosierdzia Bożego w Płocku nazywane jest również „Betlejem Miłosierdzia Bożego”, dlatego że tutaj rozpoczęło się posłannictwo siostry Faustyny Kowalskiej (w Płocku przebywała w latach 1930-1932). Sanktuarium jest miejscem pierwszego objawienia się Jezusa Chrystusa nakazującego ustanowienie w Kościele święta Bożego Miłosierdzia oraz namalowania na podobieństwo własnej postaci obrazu. Jest ono odwiedzane przez liczne rzesze pielgrzymów z całego świata, a wierni mogą m.in. pomodlić się przed relikwiami świętej i wziąć udział w nabożeństwie ku czci Bożego Miłosierdzia, które odprawiana jest 22 dnia każdego miesiąca.

Ważnym miejscem kultu Bożego Miłosierdzia jest także Sanktuarium Bożego Miłosierdzia w Białymstoku. Jego założenie wiąże się nie tylko z samą św. Faustyną, ale również z jej spowiednikiem ks. Maciejem Sopoćko, z którego inicjatywy sanktuarium powstało. Kontynuuje ono misję szerzenia Bożego Miłosierdzia zapoczątkowaną jeszcze w okresie międzywojennym w Wilnie przez siostry ze Zgromadzenia Sióstr Miłosierdzia Bożego, w którym siostra Faustyna pełniła swoją posługę. W Białymstoku przedmiotem kultu są relikwie św. Faustyny i doczesne szczątki sługi Bożego ks. M. Sopoćki. Wierni w dniach 27-29 września mogą wziąć udział w nabożeństwie ku czci Najświętszego Sakramentu związanego z dniem imienin błogosławionego ks. Sopoćki oraz 5 października - w związku z rocznicą beatyfikacji i wspomnieniem św. siostry Faustyny.

Na tle wymienionych sanktuariów Świnice Warckie są stosunkowo młodym miejscem kultu, gdyż oficjalnie ustanowione zostało dopiero w 2002 r. przez ordynariusza włocławskiego biskupa Bronisława Dembowskiego. Zainteresowanie nim wiąże się z faktem, że jest to miejsce urodzenia św. Faustyny, chrztu i pierwszej komunii, które przyjęła w miejscowym kościele p.w. św. Kazimierza Królewicza oraz doznała jednego z objawień, co zostało upamiętnione na ścianie prezbiterium. Wierni mogą obejrzeć konfesjonał, przy którym święta się spowiadała i chrzcielnicę, w której została ochrzczona oraz pomodlić się przed jej relikwiami, sprowadzonymi w 1993 r. W pobliskim Głogowcu (położonym niecałe 2 km od Świnic Warckich) zachował się domek, w którym św. Faustyna przyszła na świat i mieszkała przez pierwszych 9 lat życia. Miejscowa parafia oferuje w związku z tym szereg świąt i uroczystości, m.in. w IV niedzielę sierpnia obchodzona jest rocznica urodzin i chrztu św. Faustyny, a 25 sierpnia, w dzień jej urodzin, przy domku odprawiana jest msza święta. 


\section{Funkcja religijna Świnic Warckich}

W miejscowościach, w których znajdują się sanktuaria, funkcja religijna odgrywa najczęściej znaczącą rolę społeczną i gospodarczą. Dotyczy to zarówno większych miast (np. Rzym, Jerozolima, Częstochowa), ośrodków mniejszych (np. Lourdes, Fatima), a szczególnie małych jednostek osadniczych (np. Kalwaria Zebrzydowska, Gietrzwałd, Świnice Warckie) (Flaga 2011; Jackowskii Sołjan 2008; Jackowski i in. 2009).

Funkcję religijną miejscowości określa się zarówno jej pozycją w strukturze administracji kościelnej (np. siedziba parafii, diecezji), wielkością przybywających osób (pielgrzymów) z zewnątrz w celach religijnych (Beaujeu-Garnier za: Sołjan 2012) oraz poziomem rozwoju instytucji świadczących im różnego rodzaju usługi.

Funkcje sanktuarium wpływają bezpośrednio na funkcje religijne miejscowości, w której jest ono położone. Według I. Sołjan (2012, s. 117) sanktuaria pełnią dwie grupy funkcji: 1 - pielgrzymkową (kultyczna, ewangelizacyjna, ekumeniczna), 2 - pozareligijną (integracyjna, kulturalna, charytatywna, społeczno-oświatowa, inne). Wpływają one w istotny sposób na życie społeczne (np. w sensie integracyjnym, kulturowym), gospodarcze (np. przez rozwój usług gastronomiczno-hotelowych) oraz organizację przestrzenno-funkcjonalną miejscowości. Miejscowość Świnice Warckie pełni więc funkcje religijne w wymiarze pielgrzymkowym i pozareligiinym, w tym administracji kościelnej (siedziba parafii). Istniejące sanktuarium związane jest z miejscem urodzenia i przebywania w nim św. Faustyny w początkowym okresie jej życia i naznaczone jest pozostałymi tutaj obiektami materialnymi. Mają one kluczowe znaczenie dla formy przestrzennej sanktuarium oraz podtrzymania i rozwoju kultu Bożego Miłosierdzia. Najważniejszymi obiektami są kościół p.w. św. Kazimierza Królewicza oraz dom urodzin św. Faustyny (ryc. 3).

Kościół stoi w centrum wsi na miejscu dawnego kościoła drewnianego p.w. św. Gotarda wzniesionego prawdopodobnie w 1300 r. z fundacji arcybiskupa Jakuba Świnki. Obiekt współczesny, ufundowany w 1859 r. przez ówczesnego właściciela wsi Kazimierza Karwowskiego, jest świątynią murowaną jednonawową w stylu neoklasycystycznym z trzema ołtarzami barokowymi. W 1905 r. ochrzczona została w nim Helena Kowalska, późniejsza św. siostra Faustyna, co sprawiło, że świątynia jest jednym z najważniejszych sanktuariów Miłosierdzia Bożego w kraju. W kościele przechowywana jest większość atrybutów z nią związanych: relikwie świętej, zabytkowa drewniana chrzcielnica z XIX w., przy której została ochrzczona w dwa dni po urodzeniu, konfesjonał z 1877 r., przy którym się spowiadała oraz kopia obrazu „Jezu ufam Tobie”3 przedstawiającego postać Jezusa, który ukazał się siostrze Faustynie podczas jednego z objawień. Szczególne, wręcz symboliczne znaczenie, ma także umieszczony nad prezbiterium napis, który prezentuje słowa Jezusa usłyszane w tym kościele przez św. Faustynę podczas objawienia: „Wybranko moja, udzielę ci jeszcze większych łask, abyś była świadkiem przez całą wieczność nieskończonego miłosierdzia mojego". W świątyni tej widoczne są wyraźne odniesienia do Kościoła jako pewnej wspólnoty, uniwersum, ale też i do wydarzeń mających tutaj miejsce w 1935 r., kiedy to święta doznała pierwszych objawień. Kościół oddziałuje wyraźnie na przybywających tu ludzi, zarazem wypełniając i pogłębiając sakralność przestrzeni Świnic Warckich. Od 2002 r. dekretem ks. bp ordynariusza włocławskiego kościół ten został przemianowany na Sanktuarium Urodzin i Chrztu św. Siostry Faustyny.

\footnotetext{
${ }^{3}$ Oryginał obrazu znajduje się obecnie w Sanktuarium Miłosierdzia Bożego w Krakowie-Łagiewnikach.
} 


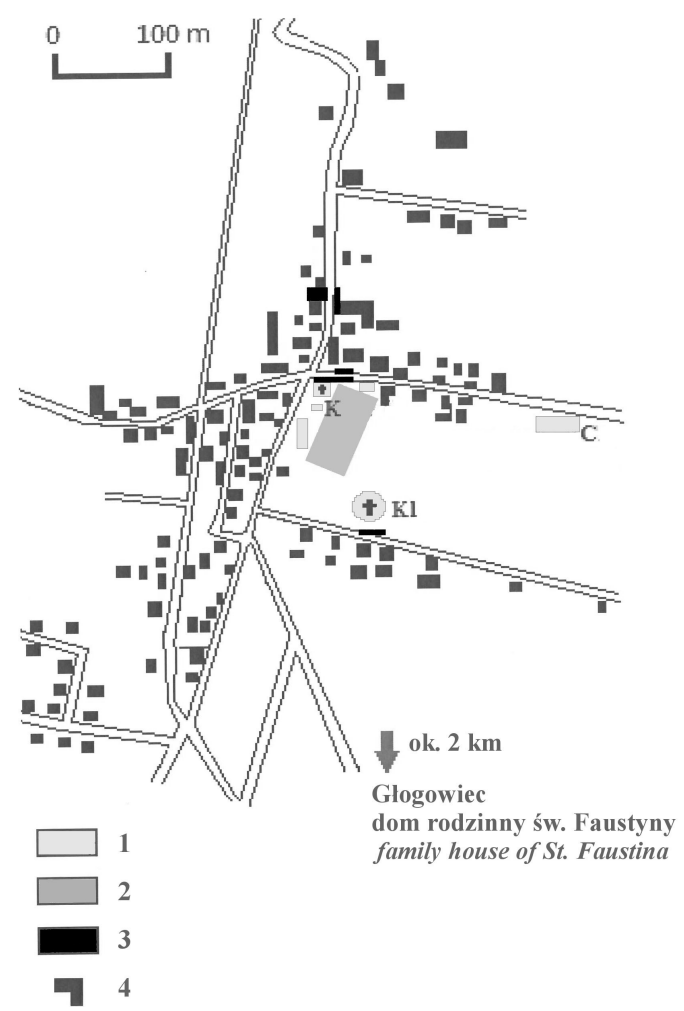

Ryc. 3. Najważniejsze obiekty związane ze św. Faustyną w miejscowości Świnice Warckie 1 - obiekty sakralne, w tym: K - kościół, KI - klasztor, C - cmentarz - grób rodziców świętej;

2 - obszar przykościelny - m.in. ołtarz polowy, alejki drogi krzyżowej; 3 - miejsca parkingowe; 4 - zabudowa. Źródło: opracowanie własne na podstawie inwentaryzacji terenowej.

Most important objects related to Saint Faustina in Świnice Warckie

1 - sacred buildings: $K$ - church, Kl-monastery, C-cemetery with the grave of Saint Faustina's parents;

2 - churchyard area: Way of the Cross alleys; 3 - parking places; 4 -other buildings.

Source: based on field inventory.

Drugim obiektem stanowiącym ważny element sanktuarium jest położony w Głogowcu, około 2 km od Świnic Warckich, domek, w którym urodziła się i spędziła wraz z rodziną pierwsze 9 lat swojego życia Helena Kowalska (tj. św. Faustyna). Budynek pochodzi z XIX w. i zbudowany jest z żółtego kamienia wydobywanego w pobliskiej wsi Rożniatów. Obecnie obiekt ten z inicjatywy miejscowego proboszcza został odnowiony i pełni funkcję muzeum, w którym prezentowana jest ekspozycja sprzętów gospodarstwa domowego państwa Kowalskich, jak również warsztat stolarski ojca Heleny. Obok domu znajduje się dawna stodoła, w której po wyremontowaniu utworzono salę wykładową dla pielgrzymów. Na placu za domem wybudowana jest droga krzyżowa i kaplica z figurką Matki Bożej oraz ołtarz polowy, przy którym odprawiane są okazjonalnie msze święte.

Skutkiem istnienia miejsca świętego (sakralnego) jest powołanie sanktuarium w sensie formalnym (uznanym przez Kościół katolicki), a jego znaczenie dla wiernych wyznacza ruch pielgrzymkowy. Świnice Warckie są bardzo popularnym ośrodkiem kultu św. Faustyny i Bożego Miłosierdzia, który odwiedza coraz większa liczba pielgrzymów. Ruch pielgrzymkowy skupia przede wszystkim kościół-sanktuarium oraz dom rodzinny (muzeum) świętej. 
Według danych uzyskanych z klasztoru Zgromadzenia Sióstr Matki Bożej Miłosierdzia w latach 2004-2015 sanktuarium odwiedziło blisko 140 tys. osób w 3200 zorganizowanych grupach, z czego 276 (prawie 9\%) pochodziło z zagranicy, w tym najwięcej ze Stanów Zjednoczonych, Portoryko, Filipin, Kanady, Meksyku, Hiszpanii, Irlandii ${ }^{4}$. W ostatnich latach zainteresowanie sanktuarium wykazywali również Chińczycy, Argentyńczycy, Białorusini i Litwini, a także Włosi. Ogółem zarejestrowano przedstawicieli z 40 różnych państw.

Organizatorami pielgrzymek są najczęściej parafie (43\%) i biura podróży (40\%), ale także zakłady pracy (10\%) oraz inne instytucje i organizacje (7\%). Wśród przyjazdów zorganizowanych wyróżnić można pielgrzymki zgłaszane wcześniej w sanktuarium o charakterze narodowym, regionalnym, diecezjalnym i międzynarodowym oraz grupy mniejsze, głównie parafialne. Wielu spośród pielgrzymów odwiedza sanktuarium regularnie co roku lub planuje tu jeszcze wrócić. Grupy pielgrzymkowe przybywają głównie autokarami i samochodami osobowymi (odpowiednio 65\% i 21\%), pozostałe to osoby przychodzące pieszo $(8 \%)$ i rowerem $(6 \%)$.

Ruch pielgrzymkowy do Świnic Warckich charakteryzuje się sezonowością w ciągu roku (ryc. 4). Zdecydowanie najwięcej przyjazdów ma miejsce w okresie od marca do listopada, w tym szczególnie w maju, czerwcu, wrześniu i październiku, co ma związek z odbywającymi się wówczas ważnymi uroczystościami kościelnymi. Między innymi w czerwcu odbywa się Dziękczynne spotkanie dzieci pierwszokomunijnych Diecezji Włocławskiej (w 2008 r. w uroczystości tej udział wzięło ponad 2300 dzieci wraz z rodzicami), a w październiku Liturgiczne Wspomnienie św. Faustyny i Zjazd Kółek Różańcowych Diecezji Włocławskiej. W każdym z tych miesięcy liczba pielgrzymów przekracza 12 tys. osób.

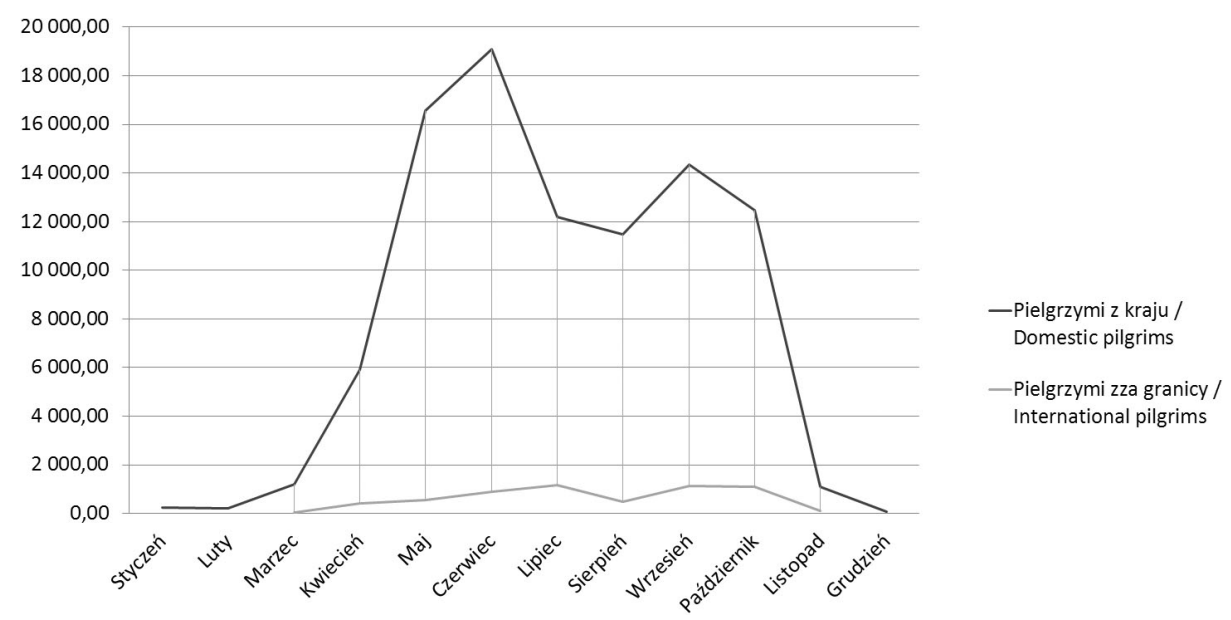

Ryc. 4. Liczba pielgrzymów z kraju i zza granicy, odwiedzających Sanktuarium Urodzin i Chrztu Świętej Faustyny w Świnicach Warckich w danym miesiącu (lata 2004-2011)

Źródło: opracowanie własne na podstawie danych uzyskanych z Klasztoru ze Zgromadzenia Sióstr Matki Boże Miłosierdzia w Świnicach Warckich.

Number of domestic and international pilgrims, visiting the Shrine of the Birth and Baptism of St. Sister Faustina in Świnice Warckie in a given month (2004-2011)

Source: own calculation based on data obtained from the convent of the Congregation of the Sisters of Our Lady of Mercy in Świnice Warckie.

${ }^{4}$ Podana statystyka dotyczy jedynie zorganizowanych grup pielgrzymkowych, które potwierdziły swoją obecność po przyjeździe do sanktuarium. Nie obejmuje ona natomiast pielgrzymów podróżujących w małych grupach oraz osób indywidualnych. 
Z wywiadów przeprowadzonych z pielgrzymami wynika, że głównym motywem ich przybycia są pobudki religijne. Najwięcej osób kieruje się potrzebą modlitwy, dialogu z Bogiem (52\% badanych) oraz potrzebą kontemplacji i wewnętrznego wyciszenia (23\% badanych). W mniejszym stopniu motywem była chęć wzięcia udziału w organizowanej przez parafię uroczystości (15\%) czy chęć zwiedzenia okolicy (11\%).

Struktura środków transportu pielgrzymów, jak i sezonowość ruchu oraz motywy przybycia (zaledwie 11\% - zainteresowanie turystyczne) wskazują, że są to przyjazdy jednodniowe i incydentalne w czasie roku oraz niemal w całości tylko z potrzeb religijnych.

\section{Wpływ kultu religijnego św. Faustyny i Miłosierdzia Bożego na organizację przestrzeni Świnic Warckich}

Parafia, poza organizacją uroczystości kościelnych i imprez związanych z kultem św. Faustyny i Bożego Miłosierdzia, podejmuje szereg działań dotyczących rozbudowy sanktuarium i całej przestrzeni sakralnej w Świnicach Warckich. Władze parafialne mobilizują również miejscową ludność do wykonywania różnych prac porządkujących zarówno obszary kościelne, jak i własne posesje. Działania te zmieniają organizację układu przestrzennego miejscowości, poprawiają jej wygląd i wizerunek w oczach pielgrzymów.

Najważniejszą inwestycją była rozbudowa obecnego sanktuarium. Prace modernizacyjne rozpoczęły się w 2005 r. od powiększenia kościoła. Nowa część świątyni liczy 170 m² powierzchni i jest połączona z obecnym kościołem przez 7-metrowy łuk w jednej ze ścian. Centrum nowej części stanowi prezbiterium, które znajduje się od strony południowej, a wejście do niego jest możliwe zarówno przez „stary” kościół, jak i z zewnątrz. Od strony zachodniej kościoła dobudowano krużganki, które umożliwiają, niezależnie od warunków atmosferycznych, przystąpienie do sakramentu pokuty. Cały kościół, stara i nowa część, jest pokryty zespolonym zadaszeniem zwieńczonym sygnaturką. We wsi odrestaurowano również dom rodzinny św. Faustyny i zamieniono go w muzeum. W 2003 r. w pobliżu kościoła, na gruntach przekazanych przez diecezję włocławską, rozpoczęto budowę klasztoru Zgromadzenia Sióstr Matki Bożej Miłosierdzia, który ukończono w 2005 r. Rok później na placu przykościelnym utworzono także Drogę Męki Pańskiej. Wytyczone alejki wyłożono kamieniem polnym oraz usypano spiętrzenie, na którym umieszczono krzyż. W przyszłości ma tutaj powstać również Golgota, do której przeniesiona zostanie figurka Matki Boskiej z Dzieciątkiem, obecnie znajdująca się w grocie na placu przykościelnym. Wokół alejek powstaną też stacje różańcowe. W zwieńczeniu placu umieszczono rzeźbę św. Faustyny. Aktualnie cały plac otoczony został krzewami, do których w 2011 r. podłączono system nawadniający. Utworzono również drogę krzyżową i kaplicę, które są dla pielgrzymów nowymi miejscami modlitwy i kontemplacji. W pobliżu plebanii z inicjatywy sióstr zakonnych, które posługują w parafii od 2001 r., wybudowano altanki wypoczynkowe dla pielgrzymów. W sąsiadującym budynku otwarto pomieszczenia sanitarne, herbaciarnię, w której można również zjeść lekki posiłek oraz sklep z dewocjonaliami i pamiątkami wytwarzanymi przez lokalnych artystów.

Istniejące sanktuarium oraz kult czyni Świnice Warckie miejscowością znaną wśród wiernych z całego świata. Realizowany przez Kościół program religijnych uroczystości przyciąga co roku rzesze pielgrzymów, co stwarza potencjalne możliwości powstawania instytucji związanych z zaspakajaniem ich potrzeb. 
Niestety władze lokalne pomimo szerokich w świetle ustawy samorządowej uprawnień nie wykorzystują istniejących zasobów religijno-kulturowych do kreowania rozwoju społeczno-gospodarczego miejscowości. Mając świadomość potencjalnych możliwości, nie wykazują inicjatywy i pomysłu na ich praktyczne wykorzystanie, co tłumaczone jest brakiem pieniędzy na inwestycje. Samorząd gminny tylko raz, w 2006 r., odwołał się do funkcji religijnej miejscowości, uzasadniając projekt unijny pt. „Dróżki św. Faustyny”, którego realizacja umożliwiła przebudowę ciągu pieszo-turystycznego w obrębie wsi. Władze planują w niedalekiej przyszłości ponowne wykorzystanie argumentu zasobów religijnych wsi do zdobycia kolejnego projektu unijnego. Inicjatywą władz lokalnych, w związku z powołaniem sanktuarium, było utworzenie w 2003 r. Punktu Informacji Turystycznej, który, jako jedyna poza parafią instytucja, działa aktywnie na różnych targach turystycznych na rzecz promocji wsi, wykorzystując m.in. informację o Sanktuarium i wizerunek św. Faustyny.

Konkludując, inicjatywa i działania miejscowego urzędu gminy w kierunku wykorzystania lokalnych zasobów religijno-kulturowych na rzecz rozwoju społeczno-gospodarczego wsi są bardzo ograniczone. Przyczyną tego stanu rzeczy jest słabe współdziałanie władz lokalnych z parafią i diecezją włocławską do której należy.

\section{Rola społeczna Sanktuarium Urodzin i Chrztu św. Faustyny}

Sanktuarium, dzięki swoim obiektom, związanym z życiem i objawieniami św. Faustyny, stanowi miejsce wyjątkowe, szczególnie dla wspólnoty katolickiej, które przede wszystkim zaspakaja potrzebę religijną człowieka, czyli potrzebę jego kontaktu ze świętością. Jego rola społeczna ma wymiar ogólny - odnosi się do pątników przybywających z różnych stron Polski i świata oraz lokalny dotyczący mieszkańców wsi.

Kult św. Faustyny i Bożego Miłosierdzia wykorzystywany jest ewangelizacyjnie oraz integracyjnie przez miejscową parafię. Jest to zasługą obecnego proboszcza, który z poczucia obowiązku oraz konieczności służby na rzecz szerzenia Bożego Miłosierdzia podjął szereg inicjatyw służących pielgrzymom. Działania parafii mają charakter religijny i są ustanowione w związku z osobą świętej i kultem Miłosierdzia Bożego. Przyjmują one następujące formy organizacyjne: Niedziela Miłosierdzia Bożego, Dziękczynna Pielgrzymka Dzieci Pierwszokomunijnych Diecezji Włocławskiej, Obchody rocznicy urodzin i Chrztu św. Faustyny, liturgiczne wspomnienie św. Faustyny, Pielgrzymka Kół Różańcowych Diecezji Włocławskiej oraz Integracyjny Festiwal Pieśni ku czci św. Faustyny „Miłosierne Nutki”. Organizowane przez parafię uroczystości i modlitwy nawiązują do sprawdzonych form, które są realizowane w innych sanktuariach. Jak twierdzi proboszcz wcale nie musi promować się w jakiś szczególny sposób, ponieważ „św. Faustyna nie potrzebuje promocji, bo, jako apostołka Bożego Miłosierdzia sama z siebie jest już promocją". Parafia bardzo dobrze wykorzystuje istniejący potencjał miejsca świętego, dokładając wszelkich starań, aby być zauważoną zarówno w kraju, jak i za granicą, o czym świadczą przybywający tutaj pielgrzymi z całego świata w liczbie ponad 13 tys. rocznie.

Kult św. Faustyny bardzo silnie oddziałuje na duchowość i poczucie tożsamości mieszkańców oraz ich społeczne więzi, zarówno z miejscem, jak i z innymi mieszkańcami, ale także z przybywającymi tutaj pielgrzymami. Deklarowana silna więź z miejscem zamieszkania wyraża się również w dobrej znajomości historii miejscowości oraz życia i działalności świętej którą znają także osoby stosunkowo młode. Zdecydowana większość responden- 
tów mówiła o Świnicach Warckich w kategorii „moja mała ojczyzna”. Mieszkańcy odczuwają dumę z faktu, że żyją w miejscu, w którym na świat przyszła święta. Żaden z pytanych mieszkańców nie wyraził chęci opuszczenia na stałe swojego miejsca zamieszkania, a 74\% badanych podało za przyczynę to, że żyją w miejscu urodzenia św. Faustyny. Wszyscy byli również przekonani i mocno wierzyli, że w szczególny sposób czuwa ona nad całą społecznością i pomaga im lepiej zrozumieć istotę kultu Bożego Miłosierdzia oraz przetrwać trudne życiowe momenty.

Wszyscy badani potrafili bezbłędnie wymienić uroczystości religijne związane z miejscowym kultem, a także deklarowali swoją obecność na nich. Wysoki poziom duchowości mieszkańców, choć trudny do zdefiniowania i zmierzenia, przejawia się między innymi w dużej otwartości wobec pielgrzymów i odwiedzających oraz zaangażowaniu w propagowanie kultu poza miastem i regionem. Większość ankietowanych stwierdziła, że bierze czynny udział w przygotowaniach parafii do różnych uroczystości i przyjęcia kolejnych pielgrzymek. Respondenci twierdzą, że bardzo chętnie udzielają schronienia i służą wszelką pomocą pielgrzymom. Przebywając poza terenem gminy, zachęcają znajomych, rodzinę czy nowo spotkanych ludzi do odwiedzenia Świnic Warckich i poznania życia oraz działalności św. Faustyny. Uzasadniając swoje zachowania, twierdzili, że „po prostu czują taką potrzebę i obowiązek, bo mieszkanie w miejscu urodzenia św. Faustyny zobowiązuje [...]".

Według oceny respondentów kult związany z siostrą Faustyną ma znikomy wpływ na ekonomiczną sferę życia mieszkańców Świdnic Warckich. Korzyści materialne z obecności pielgrzymów czerpią tylko nieliczne osoby oraz parafia. Respondenci wyrażali przy tym zadowolenie z faktu wyższych dochodów parafii ponieważ, ich zdaniem, wpływa to korzystnie na samą miejscowość. Zebrane pieniądze przeznaczane są na renowacje i rozbudowę sanktuarium i domku świętej, czyli umożliwiają ciągłe porządkowanie i upiększania ich małej ojczyzny. Mieszkańcy dostrzegają zmiany, które zachodzą w miejscowości i oceniają je pozytywnie, ale niepokoi ich brak współpracy na linii władze gminne - parafia. Zdecydowana większość respondentów uważa, że tylko wspólne i przemyślane działania mogą przyczynić się do jeszcze lepszego wypromowania ich miejscowości, poprawę warunków życia mieszkańców, a także szerzenia kultu św. Faustyny i Bożego Miłosierdzia.

\section{Podsumowanie}

Świnice Warckie dysponują unikalnymi w skali kraju wartościami religijno-kulturowymi przyciągającymi rzesze pielgrzymów, mają w najbliższej okolicy interesujące zasoby przyrodnicze i kulturowe oraz są siedzibą władz gminnych. Mimo tych wszystkich walorów trudno wieś zaliczyć do miejscowości odznaczających się szybkim rozwojem społeczno-gospodarczym.

Walory duchowe miejsca świętego konsekwentnie wykorzystuje miejscową parafia dla rozwoju sanktuarium. Dzięki inicjatywie lokalnej parafii wieś stała się jednym z najważniejszych miejsc kultu św. Faustyny i Miłosierdzia Bożego w Polsce, ale także i za granicą. Podejmowane przez parafię działania, związane z rozbudową sanktuarium i rozwojem jego wymiaru religijnego, pośrednio zmieniają organizację przestrzenną i wygląd estetyczny wsi, co zostało bardzo pozytywnie ocenione przez mieszkańców. 
Z kolei władze gminne słabo wykorzystują zasoby lokalne, które mogłyby stanowić dźwignię rozwoju społeczno-gospodarczego miejscowości i gminy. Być może wynika to zarówno z braku wiedzy i związanej z tym koncepcji działań, jak i świadomości potrzeby ich wykorzystania. Towarzyszą temu trudności we współpracy władz gminnych z parafią. W odróżnieniu od władz kościelnych, władze gminne nie mają żadnej koncepcji na uczynienie z miejscowości obszaru obsługi zintegrowanej umożliwiającej pielgrzymom i turystom pozostanie w nim dłużej niż kilka godzin. Krótkotrwały pobyt odwiedzających nie stanowi istotnego czynnika stymulującego wzrost bazy ekonomicznej miejscowości.

Świnice Warckie stanowią dobry przykład wsi, w której są wielkie możliwości zaistnienia dodatniego sprzężenia zwrotnego pomiędzy religijną tożsamością miejsca a innymi zasobami lokalnymi. Sprzężenie takie stać się może stymulantą rozwoju społeczno-gospodarczego i generować dalsze tego rodzaju efekty mnożnikowe. Jego uruchomienie powinno nie tylko spowodować czyste korzyści ekonomiczne, ale także ochronić skutecznie duchowość miejsca, która w tych zasobach lokalnych jest najcenniejsza. Przeprowadzone studia wykazały, że wieś ta znajduje się dopiero na początku tej drogi.

W artykule wykorzystano materiały zawarte w pracy magisterskiej D. Opas pt. Wpływ kultu św. Faustyny na życie mieszkańców Świnić Warckich, promotor prof. dr hab. A. Suliborski, Katedra Geografii Regionalnej i Społecznej UŁ, Łódź 2012.

\section{Literatura}

Adonai.pl (data dostępu 02.04.2016)

Bank Danych Lokalnych (BDL), 2016, GUS, Warszawa.

Czaczkowska E., 2012, Siostra Faustyna. Biografia Świętej, Wydawnictwo Znak, Kraków,

Flaga M., 2011, Sanktuaria Maryjne województwa lubelskiego - ośrodki kultu czy turystyki?, [w:] Z. Kroplewski, A. Panasiuk (red.), Turystyka religijna. Atrakcje turystyki religijnej, Zeszyty Naukowe Uniwersytetu Szczecińskiego Nr 648, Ekonomiczne Problemy Usług Nr 66, s. 111-128, dostępne na: http://yadda.icm.edu.pl (10.01.2017)

Jackowski A., 2003, Święta przestrzeń świata. Podstawy geografii religii, Wydawnictwo Uniwersytetu Jagiellońskiego, Kraków,

Jackowski A., Sołjan I., 2008, Funkcja religijna i turystyczna ośrodków pielgrzymkowych, [w:] I. Jażdżewska (red.) Funkcja turystyczna, XXI Konwersatorium Wiedzy o Mieście, t.21, s. 39-56

Jackowski A., Sołjan I., 2010, Rozwój Sanktuarium Miłosierdzia Bożego w Krakowie Łagiewnikach i jego wpływ na przemiany przestrzenno-funkcjonalne dzielnicy Łagiewniki i Borek Fałęcki, [w:] S. Ciok, P. Migoń (red.) Przekształcenia struktur regionalnych. Aspekty społeczne, ekonomiczne i przyrodnicze, Uniwersytet Wrocławski, Instytut Geografii i Rozwoju Regionalnego

Jackowski A., Bilska-Wodecka E., Sołjan I., Quarini-Popławski Ł., 2009, Pielgrzymki jako czynnik rozwoju społeczno-gospodarczego (miejscowości, regionu), [w:] Z. Górka, A. Zborowska (red.), Człowiek i Rolnictwo, Instytut Geografii i Gospodarki Przestrzennej, Uniwersytet Jagielloński, Kraków, s. 5-35.

Jackowski A., Sołjan I., Bilska-Wodecka E., 1999, Religie świata. Szlaki pielgrzymkowe, [w:] Wielka Encyklopedia Geografii Świata, t. 15, Wydawnictwo Kurpisz, Poznań, s. 359

Jan Paweł II, 2002, Encykliki Ojca Świętego Jana Pawła II, Wyd. Znak, Kraków

Klima E., 2011, Przestrzeń religijna miasta, Wydawnictwo UŁ, Łódź. 
Kodeks Prawa Kanonicznego (23.01.1983), 1984, Kan. 1230, Poznań.

Kosmaczewska J., 2011, Analiza dynamiki rozwoju ośrodków kultu religijnego na przykładzie wybranych gmin wiejskich, [w:] Z. Kroplewski, A. Panasiuk (red.), Turystyka religijna. Atrakcje turystyki religijnej, Zeszyty Naukowe Uniwersytetu Szczecińskiego, 648, Ekonomiczne Problemy Usług, 66, s. 111-128, dostępne na: http://yadda.icm.edu.pl (10.01.2017)

Liszewski S., Maik W., 2000, Osadnictwo, [w:] Wielka Encyklopedia Geografii Świata, t. 19, Wydawnictwo Kurpisz, Poznań, s. 197

Park C., 1994, Sacred Worlds. An introduction to geography and religiom, Routledge, London.

Socha P., 2000, Rozwój Bożego Miłosierdzia w Polsce i na świecie, Peregrinus Cracoviensis, 9, Kraków, s. 111-144.

Sołjan I., 2011, Sanktuarium jako organizator przestrzeni miejskiej (na przykładzie wybranych sanktuariów w Polsce), Turyzm, 21, z. 1-2, s. 49-58 dostępne na: http://turyzm.pl (09.01.2017)

Sołjan I., 2012, Sanktuaria i ich rola w organizacji przestrzeni miast na przykładzie największych europejskich ośrodków katolickich, Wydawnictwo UJ, Kraków.

Strategia Rozwoju Gminy Świnice Warckie na lata 2015-2024, rok 2015 Urząd Gminy Świnice Warckie.

\section{Summary}

Today, the primary role in the socio-economic development is played by local resources understood as a potential related to social and territorial systems at regional and local level. One of such resources comprises material and spiritual content associated with a particular religious belief. Religion has always been an important factor for local development. The increasing number of pilgrims led to establishing a settlement and gradually over time a town and vice versa a decrease in pilgrimage became a cause of economic decline and social degradation of a given locality.

The main aim of this article is to identify the Shrine of the Birth and Baptism of St. Sister Faustina in Świnice Warckie associated with the cult of Divine Mercy and its importance in the economic development and inhabitants' life in a small rural locality of Świnice Warckie. The article referred to religious and social essence of worship and sanctuary and importance of Świnice Warckie, among other iconic destinations of this type. The forms regarding the practice of this religious cult were recognized as well as its impact on economic and social life of inhabitants. 